\title{
IAMJ
}

INTERNATIONAL

AYURVEDIC

MEDICAL JOURNAL

ISSN: $2320-5091$

Impact Factor: 6.719

\section{AYURVEDIC MANAGEMENT OF BENIGN PAROXYSMAL POSITIONAL VERTIGO (BPPV) W.S.R. TO BHRAMA - A CASE REPORT}

\author{
Premcy. C. R ${ }^{1}$ S.M. Pasha ${ }^{2}$
}

${ }^{1}$ PG Scholar, Dept. of PG Studies in Shalakya Tantra, G.A.M.C, Bengaluru, Karnataka, India

${ }^{2}$ H.O.D \& Associate Professor, Dept. of PG Studies in Shalakya Tantra, G.A.M.C, Bengaluru, Karnataka, India

Corresponding Author: premcy85@gmail.com

\section{https://doi.org/10.46607/iamj3009022021}

(Published online: February 2021)

Open Access

(C) International Ayurvedic Medical Journal, India 2021

Article Received: 16/01/2021 - Peer Reviewed: 08/02/2021 - Accepted for Publication: 08/02/2021

D) Check for updates

\section{ABSTRACT}

Introduction: Benign paroxysmal positional vertigo (BPPV) is one of the most common cause of vertigo. BPPV causes brief episodes of mild to intense dizziness. It is usually triggered by specific changes in head's position. The signs and symptoms of BPPV can come and go and commonly last less than one minute. Benign paroxysmal positional vertigo can be correlated with Bhrama. This is a case report of 59-year-old male who complained of dizziness and vertigo which was associated with numbness in the right thumb and index finger since 5 months.

Materials and Method: The subject who approached Shalakya Tantra OPD of GAMC, with symptoms of dizziness and vertigo with associated symptom, numbness of right thumb and index finger was thoroughly examined, and treatment was planned based on the Doshas involved in the Bhrama. Result: The subject had shown good improvement. Discussion: Bhrama is a pithavataprakopavyadhi associated with involvement of rajas. So, treatment is focused on pacifying pithavatadoshas.

Keywords: Benign paroxysmal positional vertigo, Bhrama.

\section{INTRODUCTION}

Benign paroxysmal positional vertigo (BPPV) is an inner ear disorder in which changes in the position of the head, such as tipping the head backward, lead to sudden vertigo - a feeling that the room is spinning ${ }^{1}$. 
BPPV is the most common cause of vertigo. Brief episodes of sensation of vertigo may range from mild to moderate and lasts for few minutes. It is triggered by some specific changes in the position of head and might occur when tipping the head up and down, when lie down, or when turn over or sit up in the bed. Clinical features of benign paroxysmal positional vertigo are dizziness, vertigo, nausea, vomiting, loss of balance or unsteadiness. Usually BPPV is a benign condition but become serious when it occurs in older age people because of the fear of falling. And sometimes it may be associated with fever, diplopia, hearing loss, trouble speaking, leg or arm weakness, difficulty walking, numbness or tingling which shows its seriousness.

BPPV is caused by inner ear problem. BPPV occurs when tiny calcium crystals called otoconia come loose from their normal location on the utricle, a sensory organ in the ear. ${ }^{2}$ when the crystals become detached from the utricle, they will flow freely in the fluid filled space and enter into the semicircular canals (SCC). The otoconia in the semi-circular canals will not cause any problem until the head position changes. When it moves to the lowest part of canal stimulates the eighth cranial nerve and causing vertigo and nystagmus.

Benign paroxysmal positional vertigo can be correlated with Bhrama in Ayurvedic classics and here the treatment is given based on the Doshas involved in Bhrama.

\section{Materials and Methods}

Case Report: basic information of the patient Age: 59

Sex: male

Religion: Hindu

Occupation: retired teacher.

Chief complaints: dizziness and vertigo since 5 months.

History of present illness: The patient was apparently normal before 5 months and he suddenly developed dizziness and vertigo. After the first attack, he developed dizziness and vertigo for everyday for some specific movements such as turning head, wake up from bed, head movements during bending, closing tap etc. On consulting a physician, the subject was diagnosed to have benign paroxysmal positional vertigo. He took ECG, CT- BRAIN which showed normal findings. And also, he underwent some ear function tests suggested by the physician, like Pure Tone Audiometry and Tympanogram which showed normal hearing and 'A' type Tympanogram respectively. He took some medicines like Tab. Betavert-8mg and Tab Ginkotrack $1 \mathrm{mg}$ prescribed by them, but there was no improvement in the condition.

History of past illness: no history of Hypertension, Diabetes, Asthma, RA etc.

Family history: nothing significant

Personal history:

Appetite: good

Sleep: disturbed

Bowel: regular

Micturition: 4-5times/ day

Examination

Ashtashtanpareeksha:

Nadi: $76 / \mathrm{min}$

Mutra: 4-5 times/day

Mala: regular

Jihwa: aliptha

Shabda: parkrutha

Sparsha: anushnaseetha

Druk: prakrutha

Akruthi: madhyama

Vitals

Pulse rate: $76 / \mathrm{min}$

Respiratory rate: $22 / \mathrm{min}$

BP: 120/80mmof Hg

\section{Systemic examinations}

All systemic examinations revealed no abnormalities.

Investigations: shown in table number 1 .

\section{Diagnosis}

BPPV (benign paroxysmal positional vertigo) Diagnosis was done by DIX HALL PIKE TEST in OPD. Nystagmus was absent for both sides and dizziness was present on left side.

Treatment: patient was given treatment for a period of 2 months. Patient was administered orally Shaman aoushadhis like Drakshadi kashayam ${ }^{3} 15 \mathrm{ml}$ BD with 1 pinch Sitha, 1/4 tsp Madhu and 1 tsp Laja as Sahapana, Ksheerabala 101- 2 drops BD and Dhanvantharam 
tablet 1 BD, Vidaryadi ghrita 1 tsp at early morning in empty stomach, Avipathi churna ${ }^{5} 1 / 2$ tsp at night after food. Ksheerabala was given for local application over head

\section{Observation and Result}

Phase 1 - Drakshadikashayam and ksheerabala 101 was given for 2 weeks. Observation: initially there was no improvement. After 14 days of continuous medication there was decrease of frequency of vertigo. It reduced to once in a week. Dizziness and vertigo were absent while closing tap, turning head which shows the reduction of severity of vertigo. And also, he complained of vertigo, only while waking up from bed. Advised the patient to reduce the previous medications to half of the dose.

Phase 2 - Internally Drakshadikashayam, Ksheerabala 101, Dhanwantharma tablet, Avipathichurna and Ksheerabala for local application overhead had been given for 1 month. Observation: dizziness and vertigo were completely cured. Sometimes a sort of uneasiness was present. Advised the patient to completely stop the previous medications.

Phase 3 - Observation: subject was completely devoid of symptoms. Advised the patient to take

Vidaryadighrutha for 2 weeks.

The subject was advised to follow the proper Pathya during and after the treatment.

\section{DISCUSSION}

Benign paroxysmal positional vertigo can be correlated to Bhrama as per the symptoms. Bhrama caused due to vitiation of Pitha and Vata along with the involvement of Manoguna Rajas. So here pithavathahara line of treatment is adopted. Drakshadi kashaya and ksheerabala 101 was given for 2 weeks. For next 2 weeks dhanwantharam tablet, avipathi churna and ksheerabala application was given along with the previous medicines. After this continuous 1-month treatment the patient had shown improvement in symptoms. Only a sort of uneasiness was present. So, for curing that and for a rasayana effect vidaryadi ghrutha was given which is having vatanulomana along with pithahara action. Mode of action of particular medicine is given below.

\section{Probable mode of action of medicine}

a) Drakshadikashayam: contains Draksha, Madhuka, Mrunala, Lodhra, Kashmarya,

Patala, Amlaka, Padmakesara, Padmakam etc having Vatapithahara action. And it is indicated in Bhrama.

b) Sitha: is having Madhura rasa and is Vatapithahara

c) Madhu: Since it is having Madhura rasa and Kashaya anurasa, it pacifies the Pitha

d) Laja: pithahara, grahi, balya and rasayana

e) Ksheerabala 101: contains Bala which is Madhura rasa, along with Ksheera and Taila acts asVatahara and Pithahara

f) Dhanwantharam tablet: acts asVatanulomana

g) Avipathichurna: acts as Pithahara,

h) Vidaryadighrutha: It is having Madhura rasa, Madhura vipaka which acts as Vatashamaka. Srothoshodhaka properties of this Ghrutha helps in the clearance of channels and improves the circulation and nourishment of Dhatus. Vatanulomana and Pithashamaka properties of this medicine helps in maintenance of Agni. It is having Brumhana effect because of its Guru, Seetha, Snigdha and Mruduguna

i) Ksheerabalataila: balances Vata and Pitha, improves nerve function and good for anxiety and depression.

\section{CONCLUSION}

In the present study the BPPV is treated according to the Dosha involvement in the Bhrama. Since it is a Pithapradhanamvyadhi, Brhamana line of treatment is adopted. Later Rasayana is advised to stabilize the Doshas.

\section{REFERENCES}

1. https://my.clevelandclinic.org/health/diseases/11858enign-paroxysmal-positional-vertigo-BPPV

2. https://www.hopkinsmedicine.org/health/coditionsand-diseases/benign-paroxysmal-positional-vertigoBPPV

3. Krishnan Vaidyan K V. Sahasra Yogam. Vidyarambham Publishers. Alapuzha. $32^{\text {nd }}$ Edition. pp 29.

4. Vagbhata. Ashtanga Hridaya. Chikittsa Sthana.3/10.Aruna Datta. Reprint 2010.Chaukambha Surabharati Prakashan. Varanasi. pp710.

5. Krishnan Vaidyan K V. Sahasra Yogam. Vidyarambham Publishers. Alapuzha. 32 ${ }^{\text {nd }}$ Edition. pp 165. 


\section{Table 1:}

\begin{tabular}{|l|l|l|}
\hline SL.no. & Investigations & Reading \\
\hline 1 & WBC & $10.3 / \mu \mathrm{L}$ \\
\hline 2 & LYM $\%$ & $35.7 \%$ \\
\hline 3. & HB & $13 \mathrm{~g} / \mathrm{dL}$ \\
\hline 4. & ESR & $18 \mathrm{mmhr}$ \\
\hline
\end{tabular}

\section{Source of Support: Nil}

\section{Conflict of Interest: None Declared}

How to cite this URL: Premcy. C. R \& S.M. Pasha: Ayurvedic Management Of Benign Paroxysmal Positional Vertigo (BPPV) W.S.R. To Bhrama - A Case Report. International Ayurvedic Medical Journal \{online\} 2021 \{cited February, 2021\} Available from: http://www.iamj.in/posts/images/upload/508_511.pdf 